\title{
The role of trade unions in the HRM of Hungarian and Serbian organizations
}

\author{
Улога синдиката у активностима управљања људским \\ ресурсима у организацијама у Мађарској и Србији \\ Gyula László* \\ University of Pécs, Faculty of Business and Economics, Pécs, Hungary \\ Norbert Sipos ${ }^{* *}$ \\ University of Pécs, Faculty of Business and Economics, Pécs, Hungary \\ Agneš Slavić ${ }^{* * *}$ \\ University of Novi Sad, Faculty of Economics Subotica
}

\begin{abstract}
Industrial relations and interest reconciliation are important elements of human resource management. How to handle the employees, how to get an agreement, and how to turn them in favor of the organizational goals? These questions can be answered in different ways; the major solutions are the Michigan and Harvard model. As we see, the latter one is more employee-oriented, considering them as a partner and not as an opposing party. In this study we briefly show the role of the trade unions in the organizations in Hungary and Serbia. After discovering their theoretical constraints, we use Cranet data of 2014/16 to have a clear view in terms of empirical evidence comparing the Hungarian and Serbial results with the global ones and those of the Central and Eastern European countries. The results show that Serbia, in the eve of the EU adhesion, has an extremely high level of trade union power, while in Hungary the situation is the worst. Key words: HRM, interest reconciliation, Cranet, collective bargaining, trade unions
\end{abstract}

Сажетак: Односи измнеђу запослених и послодавца чине важан елеменат активности менаџмента људских ресурса. Како управљати запосленима, како постићи споразум, како постићи да запослени прихвате организационе циљеве? Одговори на ова питања могу бити различити. Најчешће решење се може наћи у тзв. мичигенском или харвардском моделу. Други је више оријентисан према запосленима, сматра их партнерима, а не опозицијом. У овој студији сажето се приказују улоге синдиката у Мађарској и у Србији. Након анализе теоретских органичења, користе се подаци Кранет истраживања из периода 2014-2016, с циљем да се дође до емпиријских доказа, и то поређењем ситуације у којој се налазе синдикати у Мађарској и Србији с глобалном ситуацијом и оном у земљама Централноисточне Европе. Резултати показују да у Србији, која је на корак од прикључења Европској унији, синдикати имају много већу преговарачку моћ, док је у Мађарској ситуација лошија.

Кључне речи: активности људских ресурса, усклађивање интереса, Кранет, колективни преговори, синдикати.

\footnotetext{
* $₫$ laszlo@ktk.pte.hu

** $₫$ sipos.norbert@ktk.pte.hu

${ }^{* * * *} \bowtie$ slavica@ef.uns.ac.rs
} 


\section{Introduction}

There is a fundamental paradox in every labor market that there are two different interests: on macro level, those of economic and social aspects, or on a micro level, those of employers and employees. Their (not always easy to see, nor acceptable) relationship is that while the two sides are clearly in conflict, they are mutually complementary to each other. Economic goals cannot be achieved without social peace and social cohesion, employers' goals without employees', and vice versa.

In this situation, though, both sides have the tools to accomplish their own goals, that is, in principle, it can be concluded to co-operation between the two slides, but it is very difficult, and often it is overridden by the fact that the distribution of power is mostly asymmetric. Economic interests - not just corporate, but often at governmental level - will be more important in social terms, and employers are mostly dominant due to their position in the labor market. Thus, the balance between the two sides is overcome, the weaker side tolerates it for some time, maybe it is confident toward the strong one, which the future will be better, or it is afraid that it is turning even worse, but for sure, it cannot be sustained in the long run without serious conflicts. This is the reason for creating the system of interest reconciliation, to counteract the asymmetry, to achieve equilibrium through their actions and co-operation, resolving tensions and conflicts between the two sides. The basic assumption is that both sides are able to enforce their own interest. This is also the main mission of the trade unions on the employee side.

For operating these relations, it is necessary to create an atmosphere of wise discernment, culture, acceptance, and institutionalization which does not build on its own power, dominant position, the vulnerability and abuse of the other to prevail the own interests on the short term. The purpose of the interest reconciliation is to prevent the collision, to resolve the arisen conflicts, and to make a consensus. In order to to achieve openly the identities and differences of interests and by considering and negotiating them, employers and employees will jointly try to find a situation and solution in which the originally opposing interests can be equally present. (Botelho, 2017; Karoliny \& Poór, 2017)

\section{Interest reconciliation in the context of HRM}

The interest reconcillation is not easy, often controversial because everyone wants to enforce their own aspirations in the labor market. In the literature, this can be identified very sharply in the polemics related to the Harvard and Michigan models. The basic difference is that the Michigan model 'only' places in the focus of HRM (human resource management) the owners and investors, hence it looks at employees as outsiders, non-important stakeholders, and there is no need for trade unions. While the Harvard model involves the interests and aspirations of a wide range of stakeholders (owners, line managers, employees and their groups, trade unions, governments, communi- 
ties). To articulate, represent, and to negotiate with other interests, workers are interested in setting up trade unions and stipulating collective bargaining through negotiations. (Karoliny \& Poór, 2017; Price, 2011) The 'collision' of the two models occurs in at different levels, time and space of the profession, with quite different aspects.

In the field of scientific publications, the 'strategic' principles mediate the principles of the Harvard model, but the 'practical' HR manuals follow the Michigan model. The same is true in magazines and conferences focusing on new trends: the trend and fashion is the Harvard, and the practice is the Michigan model. After the Michigan era, the Harvard model emerged more forcefully, as a response to the challenges of the 2008 crisis in the European HRM practice. This was stable in some places and elsewhere only a temporary solution. This suggests that HRM will certainly feel more comfortable in the Michigan model, but the Harvard model may have some additional strength that HRM is willing to switch to when needed. This surplus stems from the fact that HRM is able to involve trade unions, employees through them, to mobilize employees' attitudes, energies, and engagement by finding common interests in order to achieve corporate and strategic goals. (Boxall \& Purcell, 2003; László \& Sipos, 2018)

The classical attitude of employers and HRM is determined by the fact that they perceive the enemy or at least the opponent, the counterbalance to organizational decisions in the appearance of trade unions and the interest reconciliation. In our view, however, it is

- often real,

- often not, but

- in each case it is relative, mostly subjective.

So it is only up to the two sides that the ultimate outcome of the conflicts of interests will be:

a) an ever-growing conflict that can be pressed with power, but it remains; or

b) a negotiated compromise, which gives rise to mutually supportive bargains and resignations, removes the conflict, but with which sincerely, one party is not entirely satisfied because it feels that a better outcome could have been achieved; or

c) consensus, in which each of the two parties, in order to help each another and, at the end of the conciliation, seek the mutually best and satisfying solution. (Bakacsi, 2015)

Considering the other side as an enemy (from any side) necessarily leads to the application of power / hierarchical tools to be deployed against it. The given side sees that the enemy is endangering his (total) power/decision-making competence, limiting what should in no way be allowed. The result, however, can be nothing more than an oppressed, hidden or an open conflict.

The process of negotiating is certainly a power-sharing because we give concessions to the other party, giving space to the other party's power and aspirations. How- 
ever, we should also not forget that this is mutually beneficial in the agreement process. Both parties (mutually) sacrifice something, deliver something from their power, the possible result of which, in our view, does not necessarily mean a decline in power, but 'just' its rearrangement.

If the trade union finally reached a $7 \%$ wage increase instead of the initially offered $6 \%$, it would be a gain for the employees, but the employer would also have the benefit that the trade unions will be the guardian of work and employee satisfaction. If the employer in return makes accepted the new regulation of extra hours, it is a gain for it, but it also means for the trade union that the working time will be accurately accountable. Who won who grew the own power?

We need to see that negotiating with trade unions, the collective bargaining is not necessarily a zero-sum game where one side wins each and the other side loses the same. By giving birth to a mutual agreement, concessions-based agreement, both sides gave up a lot, handed over to the other side. In terms of wage increases, the employer's peace-seeking willingness was transferred to the trade union, and the trade union's working time aspiration was transferred to the employer (and to a variety of combinations of what could only be covered by a collective bargaining agreement). 'Power' as a result of the agreement, through the partner (at least in part), will also cover the internal territory of the other party, as the other side will also implement the agreement that includes theirown interests, their goals too!

In other words, it is not necessary to look at the fact that the interest of one's own party or the other party's power will be smaller or greater. But that the former power would apply unchanged, directly but with a narrow scope (only for its membership, organization) or the 'power-sharing' of the new type will result in a partially at least split, but also indirectly, a power-wielding exercise that can influence those wider new areas/dimensions. Speaking about the importance of organizational communication, Dévényi (2016) also underlines that the increased level of direct communication in organizations may reflect the decline in the trade uniuon influence.

Concerning the role of trade unions in South-East Europe, Psychogioes et al (2014) underline that the characteristics of these countries in, particularly, their past history of authoritarianism, their labour markets, the process of neoliberal reforms, the relative size of their informal economies, the expanded undeclared work and the weaknesses of their institutions contribute to understand these systems as quite distinct.

\section{The role of trade unions in Hungary}

According to Hungarian legislation, the primary aim of the trade unions is to promote and protect the employees' employment interests. It declares fundamental rights for trade unions, although it also states that social/political issues outside the employment relationship should keep trade unions away.

The trade union is entitled (inter alia): 
- to conclude a collective agreement,

- to request information from the employer regarding the employment relationships of the employees, informing the employees,

- to communicate the opinion on the employer's measures, initiating consultations,

- to represent employees against the employer or court, authority and other bodies,

- to use the employer's infrastructure for the purpose of their interest representation in accordance with the agreement with the employer. (Act I of 2012 on the Hungarian Labor Code, 2011)

The collective bargaining power of the trade unions was previously dependent on the result of the works council (WC) elections, that is, it applied the Spanish model, where the WC choice was clearly the scene of a political struggle between different trade unions. In addition, two different dimensions were covered in this solution: the works council election was about the $\mathrm{WC}$ representation, but it was extended to collective bargaining at the same time. The newer Labor Code Act of 2012 has eliminated this anomaly; the collective bargaining power depends on the degree of representativeness, the percentage of employees that the trade union can represent. The trade union will be entitled to conclude a collective agreement if its number reaches $10 \%$ of the employees.

In the German legislation, a collective agreement only applies to the members of the trade unions that are signatories (then the labor market will either transfer it to other workers or not). According to Hungarian legislation, the collective agreement covers all employees, not only the members of the trade unions that have stipulated the collective bargaining agreements

The Labor Code specifies exactly what it considers to be a cogent (where it is not possible to derogate from the law) and what is permissive, that is, a derogation. In the latter, in the majority of European regulations (and Hungarian before 2012) the principle of relative dispositivity, a derogation was allowed only for the benefit of the employee, but today's Hungarian regulation allows in many places the so-called absolute dispositivity in which the difference in the collective agreement is also allowed for the employer.

An important principle of the Hungarian Labor Code valid since 2012 is that it seeks to increase the role of corporate-level contracts against the relatively rigid legal regulations. It has therefore opened many ways of derogating from the law in both directions (for the benefit of the employer). It was complemented by the fact that if there is no contractual trade union in the institution, the works council may conclude a works agreement that almost completely replaces collective bargaining (it is not possible to agree on wages alone, but otherwise it is possible to live with the possibility of dispositivity). 
Overall, the possibility and scope of contractual, agreement-based regulation have been significantly extended by the Hungarian legal system. At the same time, however, paradoxically, but clearly pointing to the underlying philosophical intent, the frameworks of the trade unions were significantly restricted. For example, the distribution of trade union rights and their duplication between the trade unions and the works council, the significant reduction of the number of trade union officials eligible for labor protection, the reduction of the number of hours of work allowance available to officials and thus a traditional source of funding.

The Hungarian Labor Code of 2012, according to the accompanying slogan, formally declared the aspiration to develop a national flexicurity system, but in reality, it is rather unilaterally aimed at more flexibility and the employer's interest. (Act I of 2012 on the Hungarian Labor Code, 2011)

\section{The role of trade unions in Serbia}

Serbia stands around the middle of the group of ex-communist countries in terms of economic development, despite its recent turbulent history (Lane 2007). The unique background of participative structures in the former Yugoslavian countries, greatly influenced by the system of self-government, developed in the second half of the twentieth century (Svetlik et al., 2010). In the beginning of 21 th century Serbian economy is characterized by high unemployment and low growth rates. Although the country had attracted considerable inward investment it was an example of 'wild capitalism' (Upchurch \& Marinković, 2011).

In the last decades, Serbia has shown a strong effort towards democratization of IR, since this is one of the necessary conditions for its European integration. However, employee representation still seems to be uncertain. In addition to the old 'party' unions in the Confederation of Autonomous Trade Unions of Serbia, there are numerous 'new' trade unions, often set up in opposition to the former unions, many of which are not affiliated to any trade union centre. The extensive fragmentation of the union movement means that they are generally weak and have little influence. They are highly competitive between and within themselves but quiescent as far as employers or the state are concerned. They are faced with numerous problems, both of adjusting their own ways of operating and of achieving acceptance. In short, trade unionism and representation in Serbia seems to be weak, unclear and dominated by conflicts (Psychogioes et al, 2014).

Besides the effects of economic, political and social crises of the 1990s, the characteristics of the national culture (high power distance and uncertainty avoidance, explicit collectivistic and feminine values) make it difficult to implement Western management techniques in Serbia. In middle 2000nds, the HRM concept, as such, still did not exist in Serbian companies, although a growing number of companies were introducing HR departments. Most HR departments had limited functions - usually 
performing administrative tasks without a real strategic involvement. HRM responsibilities were formally a line managers' authority, but the factual responsibility was, indeed, in top managers' hands true also for Serbian subsidiaries of MNCs (VokićPološki et al, 2017).

The recent Cranet data underline that in 2014 the HRM function in Serbia had a more strategic but still moderate role, as the majority of companies did not have a general HRM strategy, and line managers still had a primary responsibility for main HRM decisions like pay and benefits, T\&D, etc. Expectedly, organizations that had more developed strategic HRM practices had better organizational performance indicators like productivity, profitability, and takingcare of environmental matters (Slavić \& Berber, 2015).

The recent study of Ladjevac (2017) underline that the trade union landscape of Serbia is still highly fragmented. Around 20 per cent of workers are organised in five rival peak organisations and a series of independent company unions. However, in response to the trade union reforms of 2014 two trade union alliances are formed. Only 30 per cent of employees fall within the scope of collective agreements in Serbia, compared with an EU average of 60 per cent

\section{Research methodology}

This current research is based on the research data of Cranfield Network of International Human Resources Management (Cranet) from 2014/16. Cranet was established in 1989, and is now a collaboration of more than 40 universities and business schools, representing different countries from all over the world. In this paper, the authors analyze the data of the latest survey round when the European sample was created by the respondent companies from 20 EU countries and four other European (Norway, Russia, Serbia and Switzerland) countries.

The research is based on the Cranet international research questionnaire which contains over 60 questions and. comprises seven main sections:

- The first section investigates the main characteristics of the Human Resource Management (HRM) department of the organizations surveyed;

- The second examines resourcing practices;

- The third deals with issues relating to employee development;

- The fourth surveys the methods used in compensation and benefits practices;

- The fifth looks for answers to questions of employee relations within the organization and the forms of organizational communication;

- The sixth features general questions on organizational data;

- The seventh records personal information on the respondent.

In 2014/16 research period, 217 companies from Hungary, and 160 companies from Serbia participated in the research. In both countries, the companies' HR manag- 
ers filled in the Cranet questionnaire concerning various aspects of HRM function. The respondents were mainly made of companies from manufacturing and service sector in private ownership. More than $50 \%$ of respondents in both countries are from SME sector.

\section{Research results}

In this section we focus on the differences and similarities of the Cranet survey of 2014/16 for the following topics: the members of the trade union, the influence of trade unions, and the right for the collective bargaining. These will be assessed in comparison of the Serbian (RS), the Hungarian (HU), the Central and Eastern European (CEE), and the global (Glob) data, by showing the possible differences between public and private sector, also.

Table 1 gives an overview of trade union membership ratios in the given country groups. Globally, we can see relatively balanced results, namely in $25 \%$ of the organizations employees do not belong to any trade union, while a relatively good, $41 \%$ declares that more than $50 \%$ of the employees are taking part of a trade union. The non-participation is almost the same for the CEE (31\%) and RS (31\%), while in Hungary is extremely high $(51 \%)$. Considering the overall data, HU is in the worst situation, because only $3 \%$ declared to have more than $50 \%$ of participation, whilst CEE and RS have $23 \%$ and $50 \%$ respectively. The latter result is an outstanding and good sign as Serbia is in the eve of adhesion to the EU.

Table 1: Trade union membership, 2014/16

\begin{tabular}{|l|r|r|r|r||}
\hline \hline Ratio & Glob & CEE & \multicolumn{1}{|c|}{$R S$} & \multicolumn{1}{c|}{$H U$} \\
\hline $0 \%$ & $25 \%$ & $31 \%$ & $31 \%$ & $51 \%$ \\
\hline $1-10 \%$ & $21 \%$ & $18 \%$ & $6 \%$ & $22 \%$ \\
\hline $11-25 \%$ & $11 \%$ & $14 \%$ & $6 \%$ & $16 \%$ \\
\hline $26-50 \%$ & $12 \%$ & $13 \%$ & $8 \%$ & $8 \%$ \\
\hline $51-75 \%$ & $14 \%$ & $13 \%$ & $22 \%$ & $2 \%$ \\
\hline $76-100 \%$ & $17 \%$ & $10 \%$ & $28 \%$ & $1 \%$ \\
\hline Total & $100 \%$ & $100 \%$ & $100 \%$ & $100 \%$ \\
\hline
\end{tabular}

Considering the respondent organization sectors, we can observe significant differences. In the private sector, $30 \%$ do not have any members globally, while in CEE 39\%, in RS 43\%, andin HU 66\%. The high level of participation ratios are worst, only $23 \%$ globally. In CEE it is not a common example (17\%), and in Hungary it is almost nonexisting (2\%). Even in this case, Serbia is an outlier in a good way, as $36 \%$ of the organizations has more than $50 \%$ of participation in the trade unions. 
The public sector is totally different, globally only $9 \%$ declare to not having trade unions at all. CEE has the same number, while RS is characterized by an even lower one $(6 \%)$. In HU it is a way higher $(20 \%)$. The high level of participation in the Glob group is $55 \%$, it is $41 \%$ for CEE, and RS states that a great majority of the organizations $(75 \%)$ has an extended membership. Not surprisingly, in HU it is not a common thing $(6 \%)$ either.

The level of influence (see Table 2) can turn everything upside down, as even a small, but fierce trade union can achieve a lot, while contrary a large but peaceful almost nothing. The general results confirm the previous tendencies, that is, we can see a moderate proportion of no influence at all for Glob and RS, a little higher for CEE, and an extremely one for HU. The high or very high influence is $25 \%$ for global, and $20 \%$ for CEE groups. However, RS has once again, better data, and HU the worst. This also means that parallel to the lower membership trends for Hungary, unfortunately, lower level of influences can be observed, also.

Table 2: Trade union influence on organizations, 2014/16

\begin{tabular}{|l|r|r|r|r|}
\hline Ratio & Glob & \multicolumn{1}{|c|}{ CEE } & \multicolumn{1}{|c|}{ RS } & \multicolumn{1}{|c|}{$H U$} \\
\hline No influence & $34 \%$ & $43 \%$ & $32 \%$ & $67 \%$ \\
\hline Low influence & $20 \%$ & $18 \%$ & $8 \%$ & $18 \%$ \\
\hline Moderate influence & $22 \%$ & $19 \%$ & $10 \%$ & $4 \%$ \\
\hline High influence & $14 \%$ & $10 \%$ & $5 \%$ & $2 \%$ \\
\hline Very high influence & $11 \%$ & $10 \%$ & $45 \%$ & $100 \%$ \\
\hline Total & $100 \%$ & $100 \%$ & $100 \%$ & \\
\hline \hline
\end{tabular}

Source: Authors' own elaboration based on Cranet 2014/16

In $40 \%$ of private organizations there is no influence at all globally; while in CEE countries it is $51 \%$. Even for RS is it a little higher than the average (45\%), and as expected, HU is characterized by the worst ratio (76\%). The high and very high level of influence is almost the same for Glob (20\%) and CEE (16\%). Considering the previous information, it is quite normal, that HU has only $5 \%$, and RS $37 \%$.

For the public sector, $17 \%$ of the respondentsstates that the trade unions have no influenceat all globally, while for CEE it is $23 \%$. In the case of RS, almost every organization has a positive opinion about the capabilities of the trade unions $(95 \%)$. The Hungarian result is very negative, even if a little better than for private ones $(51 \%)$. On the other side, $41 \%$ declares to have high or very high influence at the global level and $32 \%$ in the case of CEE. Almost none of the organizations belong to this category in $\mathrm{HU}$ and $78 \%$ of the Serbians communicated high level of influence. 
Table3: Trade union right to negotiate and stipulate collective bargaining, 2014/16

\begin{tabular}{|l|r|r|r|r||}
\hline $\begin{array}{c}\text { Collective } \\
\text { bargaining }\end{array}$ & Glob & \multicolumn{1}{c|}{ CEE } & \multicolumn{1}{c|}{$R S$} & \multicolumn{1}{c|}{$H U$} \\
\hline Public sector & $83 \%$ & $76 \%$ & $93 \%$ & $50 \%$ \\
\hline Private sector & $63 \%$ & $47 \%$ & $50 \%$ & $22 \%$ \\
\hline Total & $68 \%$ & $55 \%$ & $65 \%$ & $32 \%$ \\
\hline
\end{tabular}

Source: Authors' own elaboration based on Cranet 2014/16

In $65 \%$ of analyzed RS organizations, the trade unions are recognized in the purpose of collective bargaining. In the privatesector, it happens in the half $(50 \%)$ of the organizations, while in the public sector in the vast majority (93\%) of analyzed organizations. It is partly different from the global data, as in their case a slightly higher ratio of private company trade unions are recognized for this purpose, while the general ratio is almost the same. CEE countries are quite similar to the Serbian situation regardingthe private sector, but the public sector trade unions are less recognized. In Hungary, both the private as the public company trade unions are less recognized, as it is quite the consequence of the a priori mentioned and listed factors.

The results of the Cranet surveys (Poór et al, 2018; Poór et al, n.y.) clearly support the effects of the crisis at the micro level, i.e. in Central and Eastern Europe (but typically in the whole world) the strengthening of the trade union organization, the development of the opposition, while in a predictable environment rather the individual bargaining will prevail. This also means that basically in 'normal' circumstances, the relative economic prosperity generally has a negative impact on the various forms of interest reconciliation, the Michigan model comes to the fore, and the workers do not counteract. At the time of the crisis, due to the greater willingness to organize and the more robust appearance of the emotional side, the Harvard model is chosen at a micro level. This is supported by the practice of interest reconciliation and its changes as a result of the crisis, since then there is a negative response from governments (typically in the Michigan model approach), i.e. there is an actor to whom it is worth seeking collaboration and coalitions.

That is, in the vast majority of labor markets, professions, occupational groups and forms, positions, the balance of power, priority rankings and deficit lists have changed or changed. (Boughton \& Welz, 2013) The theoretical considerations and the practical experience both we have outlined in the direction of changing the HRM's capital approach, value system, internal and external labor market segmentation, attitudes and methods, whether they like it or not or agree whether or not it is.

\section{Conclusions}

In several documents, it has already shown that the EU is basically seeking for a partnership-oriented dialogue between European trade unions and employers' associations 
and the strong involvement and participation of social partners in the design and implementation of socio-economic policies. This is equally valid for micro-level relationships, as well.

Of course, we know that probably not any political or interest reconciliation group fully agrees with this. But, in our view, especially when there is a need for solutions on the labor market in crisis, when competitiveness is to be steadily increased, when economic and social aspects are to be coordinated, when a country faces significant changes and challenges (such as Serbia's on the eve of the EUaccession), it is very important to strengthen the socio-economic base, reduce the potential tensions, and strengthen partnership. The Cranet results show that in Serbia there is higher participation in the interest reconciliation processes than in Hungary, with higher potential level of influence and recognition for stipulating the collective bargaining.

For the future, we plan to carry out the same investigation among the Central and Eastern European countries to identify the similarities and differences between the historical development of interest reconciliation and industrial relations as a whole. We think that this exploratory survey (using the same methodology) will contribute to the better understanding of the actual situation, power and future opportunities of trade unions. In addition, it is also providing an opportunity to create international relations, and thus, to have better chances of developing a Harvard model in the given countries.

\section{References}

Act I of 2012 on the Hungarian Labor Code (2011). Retrieved November 7, 2018, from http://www.ilo.org/dyn/travail/docs/2557/Labour\%20Code.pdf

Bakacsi, Gy. (2015). A szervezeti magatartás alapjai (The fundamentals of organizational behavior) Budapest: Semmelweis Kiadó.

Botelho, C. (2017). The Role of Human and Social Capitalon the Influence of HR Practices on Organizational Performance. Proceedings of the European Conference on Intellectual Capital, pp. 26-33.

Boxall, P. \& Purcell, J. (2003). Strategy and human resource management. London: Palgrave Macmillan.

Broughton, A. \& Welz, C. (2013). Impact of the crisis on industrial relations. Dublin: European Foundation for the Improvement of Living and Working Conditions, Retrieved November 15, 2018, from https://www.eurofound.europa.eu/observatories /eurwork/comparative-information/impact-of-the-crisis-on-industrial-relations.

Dévényi, M. (2016). The role of integrative strategies and tactics in HR negotiations. Strateg. Manag, 21(2), 32-36. 
78 Gyula László, Norbert Sipos, Agneš Slavić

Karoliny, M., \& Poór, J. (Eds) (2017). Emberi erőforrás menedzsment kézikönyv (Human Resource Management Handbook). Budapest: Wolters Kluver.

Ladjevac B. (2017). Trade unions in Serbia on the move? Berlin: Friedrich Ebert Stiftung.

Lane, D. (2007), 'Post State Socialism: A Diversity of Capitalisms?' in Varieties of Capitalism in Post Communist Countries, eds. D. Lane and M. Myant, London: Palgrave, pp. 13-39.

László, Gy. \& Sipos, N. (2018). Kell-e nekünk érdekegyeztetés? (Do we need interest reconciliation?) Vezetéstudomány, 49 (10-11), pp. 112-119.

Poór, J., Juhász, T., Szabó, K., Kovács, I. É. \& Karoliny, M-né (2018). A külföldi tulajdonú vállalatok emberierőforrás-menedzselésének jellegzetességei és sajátos kontingencia faktorai Kelet-Közép-Európában (The characteristics of HRM activities of foreign-owned companies and their contingency factors in Central and Eastern Europe) Vezetéstudomány, 49 (1), pp. 40-52.

Poór, J., Karoliny, M., Kovács, I. É. \& Illés, B. Cs. (eds.) (n.y.). A HR gyakorlata (The Practice of HRM). Budapest: Wolters Kluwers.

Price, A. (2011). Human Resource Management. Donnelly: Cengage Learning EMEA.

Psychogios, A., Brewster, C., Missopoulos, F., Kohont, A. Vatchkovae, E. \& Slavic, A. (2014). Industrial relations in South-Eastern Europe: disaggregating the contexts. The International Journal of Human Resource Management, 25 (11), pp. 1592-1612.

Slavić, A., \& Berber, N. (2015). The role of HRM function in Serbian companies and its contribution to the companies' performances - based on the results of the CRANET research in 2008 and 2015. A paper presented at the "2nd International Conference on Management, Enterprise and Benchmarking”, Cluj-Napoca, Romania.

Svetlik, I., Barasic, F.A., Kohont, A., Petković, M., Mirić, A. A., Slavić, A., Voput, Z., \& Poór, J. (2010). Human Resource Management in the Countries of the Former Yugoslavia, International Journal of Human Resource Management, 11, 5, pp. $807-$ 833.

Upchurch, M. \& Marinković, D. (2011). Wild Capitalism, Privatization and Employment Relations in Serbia, Employee Relations, 33 (4), pp. 316-333.

Vokić Pološki N., Kohont A. \& Slavić A. (2017). Is there something as an ExYugoslavian HRM model? - Sticking to the socialist heritage or coverging with neoliberal practices, Our Economy - Journal of Contemporary Issues in Economics and Business, 63 (4) pp. 40-53. 


\section{Summary}

Industrial relations and interest reconciliation are important elements of human resource management. The interest reconcillation between employers and employees is not easy, often controversial because everyone wants to enforce their own aspirations in the labor market. The legislation in Hungary declares fundamental rights for trade unions, although it also states that social/political issues outside the employment relationship should keep trade unions away. In Serbia the trade union landscape is still highly fragmented. The paper briefly presents the role of the trade unions in the organizations in Hungary and Serbia. The results concerning the trade union membership, the trade union influence and their right to negotiate in collective bargaining show that in Serbia there is an extremely high level of trade union power, while in Hungary the situation is worse. 